UDC 94(477.82) «1943/1944»

DOI: 10.24919/2519-058x.12.177562

\title{
Volodymyr TROFYMOVYCH
}

PhD hab. (History), Professor, Head of Mykola Kovalskyi Department of History of the National University of Ostroh Academy, 2 Seminarska Street, Ostroh, Rivne region, postal code 35800,Ukraine (trofymovych@hotmail.com)

ORCID: http://orcid.org/0000-0003-0083-0437

ResearcherID: G-7435-2019 (http://www.researcherid.com/rid/ G-7435-2019)

Scopus ID: 57188979113

(https://www.scopus.com/authid/detail.uri?authorId=57188979113)

\section{Andriy SUKHYKH}

Applicant of Mykola Kovalskyi Department of History of the National University of Ostroh Academy, 2 Seminarska Street, Ostroh, Rivne region, Ukraine, postal code 35800 (andrew. sukhykh.1992@gmail.com)

ORCID: http://orcid.org/0000-0002-5787-2841

ResearcherID: G-7755-2019 (http://www.researcherid.com/rid/ G-7755-2019)

\section{Володимир ТРОФИМОВИЧ}

доктор історичних наук, професор, завідувач кафедри історії імені М. П. Ковальського Національного університету «Острозька академія», вул. Семінарська, 2, Острог, Рівненська область, Украӥна індекс 35800 (trofymovych@hotmail.com)

\section{Андрій СУХИХ}

здобувач кафедри історії імені М. П. Ковальського Національного університету «Острозька академія», вул. Семінарська, 2, Острог, Рівненська область, Україна індекс 35800 (andrew.sukhykh.1992@gmail.com).

Бібліографічний опис статті: Trofymovych, V., \& Sukhykh, A. (2019). Struggle for provisions between soviet partisans and Ukrainian insurgents in 1943 - 1944 in Volyn region. Skhidnoievropeiskyi Istorychnyi Visnyk [East European Historical Bulletin], 12, 149-158. doi: 10.24919/2519-058x.12.177562

\section{STRUGGLE FOR PROVISIONS BETWEEN SOVIET PARTISANS AND UKRAINIAN INSURGENTS IN 1943 - 1944 IN VOLYN REGION}

Summary. The aim of the research - on the basis of the source base and the historiographic work to highlight the reasons the struggle process for provisions between the Soviet partisans and Ukrainian insurgents in 1943 - 1944 in Volyn region. The principles of a scientific objectivity and historicism are the methodological basis of the study. The scientific novelty of the obtained results is determined by the fact that for the first time in a domestic and foreign historiography the struggle for provisions between the Soviet partisans and the Ukrainian insurgents in Volyn during the specified period has been analyzed, as well as the unpublished archival documents and the materials have been introduced into the scientific circulation. Conclusions. The struggle for the provisions between the Soviet partisans and the units of the Ukrainian Insurgents Army was the result of their confrontation aggravation over the 
range of influence. The unsettled rear support of the Soviet partisans pushed them into carrying out the preplanned "provisions» ("food》) operations of the peaceful and armed character, a forced alienation of food from the population, loyal to the Ukrainian nationalists. Acting this way, the Soviet partisans tried to deprive the latter of their food supplies and level off the Ukrainian insurgents' main advantage in Volyn region - the support from a part of the local residents, who became the members of Ukrainian Insurgents Army (UPA), and to cause the significant economic losses to the insurgent rear. An effective way of depriving the UPA and the OUN (Organization of Ukrainian Nationalists) underground of the provisions and property was the requisition of their food warehouses. The Soviet Union partisans had a significant distribution of the provisions in this way since the end of 1943, and especially in the first half of 1944, when the number of the partisan associations increased in connection with the approaching of the front in Volyn. Under such conditions, the Ukrainian nationalist underground lowered its activity, and the insurgents divisions, in order to avoid losses, crashed into the smaller groups.

Thus, the local population turned out to be the hostage of the situation, having fallen under the pressure of both "the forest armies», since both the Soviet partisans and the members of UPA put their back and food on it. The replenishment of the food stocks by the hostile forces often turned into the military operations.

Key words: the Soviet partisans, Ukrainian nationalists, insurgents, UPA, struggle, provisions, local population, Volyn.

\section{БОРОТЬБА ЗА ПРОДОВОЛЬСТВО МІЖ РАДЯНСЬКИМИ ПАРТИЗАНАМИ Й УКРАЇНСЬКИМИ ПОВСТАНЦЯМИ НА ВОЛИНІ У 1943 - 1944 pp.}

Анотація. Мета дослідження - на основі джерельної бази та історіографічного доробку висвітлити причини і перебіг боротьби за продовольство між радянськими партизанами і українським повстансько-підпільним рухом на Волині в 1943 - 1944 рр. Методологічною основою дослідження стали принципи наукової об' єктивності та історизму. Наукова новизна одержаних результатів визначається тим, щзо вперше у вітчизняній і зарубіжній історіографії проаналізовано боротьбу за продовольство між радянськими партизанами й українськими повстаниями на Волині зазначеного періоду, а також упроваджено до наукового обігу неопубліковані архівні документи та матеріали. Висновки. Боротьба за продовольство між радянськими партизанами та відділами Української повстанської армії була наслідком загострення їхнього протистояння за терени впливу. Невирішеність тилового забезпечення радянських партизанів штовхала їх до проведення спланованих «господарських» («продовольчих») операцій мирного та збройного характерів, примусового відчуження продуктів харчування $і$ майна у лояльного до українських начіоналістів населення. Тим самим вони намагалися позбавити продовольчих запасів останніх і нівелювати їх головну перевагу на Волині - підтримку з боку частини місцевих жителів, за рахунок яких поповнювала свої лави УПА, а також завдати значних економічних втрат повстанському запіллю. Дієвим способом позбавлення упівців й оунівського підпілля продовольства та майна були реквізииї̈ їх продовольчих складів. Значного поширення заготівля харчів радянськими партизанами набула з кіния 1943-го й особливо у першій половині 1944-го рр., коли у зв 'язку з наближенням фронту на Волині збільшилася кількість партизанських з'єднань. У таких умовах украӥнське націоналістичне підпілля знижувало свою активність, а повстанські відділи, щоб уникнути втрат, розбивалися на менші групи.

Таким чином, місцеве населення виявилося заручником ситуації, потрапивши під тиск обох «лісових армій», оскільки і радянські партизани, і упівиі покладали на нього своє тилове та продовольче забезпечення. Поповнення продовольчих запасів протиборчими силами нерідко перетворювалося на військові операції.

Ключові слова: радянські партизани, украӥнські націоналісти, повстаниі, УПА, боротьба, продовольство, місиеве населення, Волинь.

The problem statement. The confrontation between the Soviet partisans and the Ukrainian rebel-underground movement caused a considerable interest of Ukrainian and foreign scholars. However, the struggle for provisions between the hostile armies remains unstudied, as the researchers mostly analyzed the military confrontation, which, among other 
areas of the interaction between the Soviet partisans and the Ukrainian insurgents, most affected the overall course of the confrontation.

A complex study of the struggle for the provisions will determine the impact of the confrontation on the lives of the local population, the additional factors in shaping its sociopolitical sentiment, deepen understanding of the inter-partisan conflict and the general situation in Volyn during the German occupation.

The analysis of recent researches and publications. In the historiography of the Soviet era, the attention was paid to the study of the partisan movement, controlled by the state party bodies, but the solution to the provisions issue was considered incidentally, since the authors adhered to the concept of the «all people» support in the rear of the enemy. The Soviet era historians, who covered the partisan movement in Volyn (V. Zamlynskyi (Zamlynskyi, 1965), L. Kyzia (Kyzia, 1960), L. Stepanov (Stepanov, 1966)), noted that the Soviet partisans had to fight with the Ukrainian nationalists, but they did not mention that there was also the struggle for the provisions.

In American historiography, the activity of the Soviet partisans was actively studied by the scientist J. Armstrong, who, unlike the historians of the USSR, drew attention to the conflict situations in the relations between the Soviet partisans and the local population, which became the cause oof products and equipment requisition (Armstrong, 1980; Armstrong, 2007 ). However, the situation, which existed in Ukraine during the war and, moreover, in Volyn, was poorly reflected in J. Armstrong's works.

Since the proclamation of the independence of Ukraine, the historians-archaeologists A. Kentii and V. Lozytskyi have the most accomplished researches on the theme of the local Soviet partisan movement. Despite their significant contribution to the study of this problem, the struggle issue for the provisions between the Soviet partisans and the rebel underground was not specifically developed by them (Kentii \& Lozytskyi, 2005; Kentii, 2008; Kentii \& Lozytskyi, 2010; Kentii, Lozytskyi \& Slobodianiuk, 2010). O. Gogun, a famous RussianGerman researcher of the partisan movement, also only noted that the struggle for the provisions between the above-mentioned hostile armies took place (Gogun, 2012). In addition, it is worth mentioning the works of H. Starodubets, who, studying the Ukrainian insurgent movement, argued that the Soviet partisans pose a serious danger to the Ukrainian insurgents, although she did not analyzed it in details (Starodubets, 2006; Starodubets, 2008). O. Perekhrest, investigating the Ukrainian peasantry from 1941 to 1945 , analyzed it in the context of supporting the Soviet partisan and Ukrainian liberation movements, omitting the struggle for the provisions between the hostile forces in Volyn (Perekhrest, 2011).

As we see, the struggle for the provisions between the Soviet partisans and the Ukrainian rebel-underground movement in Volyn during the German occupation has hardly been developed in historiography, therefore, this topic requires a thorough study and the formation of the relevant conclusions.

Statement of the basic material. The Soviet partisan units and the Ukrainian insurgents divisions should be classified as the paramilitary formations of the «Small War», for whom the relations with the local population played an important role. The aggravation of the relations with the latter posed a danger to the disclosure by the occupiers or the hostile partisans of the forest camps locations, as well as the complexity of the food supply, which, to a large extent, affected the tactics of the partisan forces.

For the Ukrainian insurgents in Volyn, the issue of the proper products supply during the German occupation, in fact, had never been acute. Since they were mostly local, they could rely on the material support of the peasantry, and the economic references of the rear, 
the core of which was the organizational network of the OUN (b), regularly provided their departments with the provisions, provided by the population.

The Soviet partisans, in this regard, were in the worst conditions, because they hoped to be supported by the local population only in the areas of the stable dislocation of their own units, which, as a rule, were removed far from the locations with favourable conditions for agriculture and livestock farming. In addition, as the archival materials run, the partisans received supplies, from time to time, from the "Great Earth», which consisted mainly of weapons, ammunition, clothes, medicines. But those from time to time supplies didn't solve the urgent issue of the provisions (Central State Archives of Public Associations of Ukraine CSAPAU, f. 69, d. 1, c. 1, p. 27; CSAPAU, f. 70, d. 1, c. 1, p. 176; CSAPAU, f. 78, d. 1, c. 1, p. 151 ; CSAPAU, f. 88 , d. 1, c. 1 , p. 347 ).

The food situation in the partisan detachments worsened as a result of the punitive and repressive measures of the German occupiers. For example, in Horodnytskyi district of Zhytomyr region, most of the villages were burned for the cooperation with the Soviet partisans, creating there the so-called «dead zone», which, in particular, was noted by the commander of the union of the cavalry partisan detachments M. Naumov and, on the other side, by the commandant of the Kostopil district of the OUN (b) «Dolyna (Valley)» (Kovalchuk, 2007, p. 349; Bazhan, Vlasenko, Kentii, Legasova \& Lozitskii, 2010, p. 288). Since in the abovementioned village, some of the locals remained without farms or died, the Soviet partisans, who were deployed there, lost their food supply and therefore repeatedly carried out operations on the adjacent villages of Korecchyna, Ludwypilshchyna, and Bereznenshchyna, which were located west of the Sluch river, where Banderivtsi had some support (Sukhykh, 2014, p. 373).

In the areas, controlled by the Soviet partisans, the peasants were mostly forced to provide food support to the extent that they could provide. However, the partisans violated the discipline repeatedly, appropriating the food and property of villagers by force. Often, such «operations» took place without the authority commands of the detachments, on the initiative of the partisans themselves, who took not only the food, but also personal belongings from the locals. H. Balitskyi, the commander of the detachment named after J. Stalin of ChernihivVolyn Partisan Unit (CHVPU), analyzing the consequences of the uncontrolled preparations, noted in his diary reasonably: «We will behave properly among the peasants, then the enemy will never have sympathizers; but if the partisans forget about the correct behaviour of the party's policy and the Soviet regime among the civilian population, then the enemy will necessarily use all this [...]. It is better not to get rid of 10 nationalists or policemen than to take those or other things from one honest citizen» (Bazhan, Vlasenko, Kentii, Legasova \& Lozitskii, 2010, p. 481).

During the implementation of the provisions requisites, the Soviet partisans were guided with a class approach, when selecting the persons, who should be deprived of their property. In Volyn, the Ukrainian nationalists were also referred to the «Kurkul» group by the Soviet partisans. In particular, F. Bokalchuk, the political head of the artillery division of Rivne Partisan Unit (RPU) No. 1, noted: «Some partisans allowed looting, believing that the nationalists and their sympathizers could be deprived of their property, especially since winter conditions require warm clothes and not all partisans have it» (CSAPAU, f. 69, d. 1, c. 7, p. 27).

The uncontrolled requisitions prompted the partisans' authorities to issue the orders on the prohibition to leave the partisan camps unilaterally and to stop looting, drinking, and the inappropriate relations with the local population. For example, such an order was issued by Rivne Regional Headquarters of the Partisan Movement (RRHPM) on July 15, 1943 (CSAPAU, f. 70, d. 1, c. 6, p. 28). His chief, V. Behma, justified the the partisans behaviour, 
noting that «the commanders and commissars of the units did not take into account the specific conditions in Western Ukraine, where the national hostility was greatly developed» (CSAPAU, f. 70, d. 1, c. 6, p. 36, p. 38).

There were frequent misunderstandings among the partisans of different units when the issue concerned the choice of the village, planned for the provisions operations. In the letter dated December 19, 1943, I. Fedorov, the commander of RPU No. 2, suggested O. Fedorov, the commander of ChVPU, a division of the area, since «the people are offended» of the so called double «taxation» (Kentii, Lozytskyi \& Slobodianiuk, 2010, p. 38). It is worth mentioning the conflict situation between the partisans of $\mathrm{O}$. Fedorov and the partisans of Brest region, which arose for the right to procure the provisions in the villages of Svaryn, Radoslav and surrounding farms. On November 20, 1943, the Belarusian partisans issued the order, in which they warned of the ban on requisitions in the mentioned villages, where «all movable and non-movable property as well as all food and feed resources [...] are intact and under the control of the command p[artisan] units of Brest region» (CSAPAU, f. 64, d. 1, c. 92, pp. 2-3). In response, O. Fedorov sent a radiogram to S. Hryhorenko, the head of the headquarters of V. Chapayev detachment, in which he was allowed to carry out harvesting of the agricultural products and warm clothes, noting that «if such silly ones would hinder, disarm and fight» (CSAPAU, f. 64, d. 1, c. 92, p. 1).

Thus, looting and the chaotic requisitions made by the Soviet partisans in the territories under their control occurred as a result of the disorganization of the provisions supply in the units, the lack of discipline, and were the result of a significant change in the moral attitudes under the influence of hostilities.

The UPA, without the external sources of supply, depended on the stability of the insurgent rear. In the latter, the mandatory food tax for the population was established on the principle of a social justice, spreading not on the amount of farms, but depending on the amount of land (Starodubets, 2008, p. 149). At the same time, as H. Starodubets noted, the expediency of the tax introduction on the population in the rear was decided unevenly in different regions, and in the autumn of 1943, its establishment was not a widespread practice (Starodubets, 2008, pp. 155-156).

In the end, as a result of the optimal way of the provisions harvesting by the UPA, the local population more easily tolerated the provisions harvesting as compared to the provisions harvesting operations by the Soviet partisans. In addition, in Volyn the insurgents managed to interfere with the majority of the planned requisition of the German invaders, preserving the provisions to replenish their departments. Therefore, the economic situation in the area where the UPA «managed» to succeed was much better than the dislocation areas of the partisan forces of the Ukrainian Partisan Movement (UPM).

The places of the provisions operations, especially after the intensification of the confrontation over the influence range between the Soviet partisans and the Ukrainian insurgents, were determined both in the aspect of the local population loyalty and the economic situation in the region. Often, the provisions requisites of the Soviet partisans in Volyn occurred in areas under the control of the UPA, which aimed at not only replenishing food, but also the implementation of the peculiar anti-rebellious measures or «repaid actions» that, according to O. Gogun, may be considered as an economic repressions or economic terror. The obtained provisions, as a result of such operations, was used not for the personal purposes, but for the purpose of the warfare (Gogun, 2012, p. 392). It is worth noting that during such «operations» the villages, where rebel units were located or the locals were loyal to the nationalists, the Soviet partisans considered those villages as the provisions storehouse 
or the occupiers' enterprises. The Soviet partisans often attacked those kind of villages. For example, on October 10, 1943, O. Fedorov, the ChVPU commander, authorized P. Markov, the commander of K. Voroshylov detachment «at the expense of the nationalists and their families to dress warriors for the winter by confiscation» (CSAPAU, f. 64, d. 1, c. 17, p. 113).

The Soviet partisans of S. Kirov detachment also planned to provide themselves with the provisions, using the Ukrainian nationalists. On November 14 the partisans of the above-mentioned detachment went to the village of Volochynsk with the task of killing 40 nationalists and carrying out provisions and clothes operations in the families, who grew potatoes. However, they failed to do this because the occupants almost completely burnt the village, and so the Soviet partisans went to the village of Troyanivka, Manevytskyi district, where they organized the provisions requisition of the «enemy people» (CSAPAU, f. 64, d. 1, c. 85, p. 27). I. Shyshko's detachment from the Kamyanets-Podilskyunit also succeeded in the practice of providing the partisans with clothes and food by requisitioning them from the nationalists. On October 22 the above-mentioned detachment realized requisitioning in Chermyn (CSAPAU, f. 102, d. 1, c. 1. p. 31). Thus, the Soviet partisans of V. Behma unit also took the provisions and clothing from the village of Yasynets, Dubrovytskyi district on December, 22 (CSAPAU, f. 69, d. 1, c. 6, p. 123).

Since the summer of 1943, between the UPA and the red partisans the struggle for food intensified, since at that time in Volyn there already operated several Soviet units, requiring the additional food supplies. Of course, the first information on the property appropriation of a disloyal local population can be found in the reports and messages of the hostile armies during the previous months, but the frequency of such cases was low at that time.

The struggle of the Soviet partisans against the Ukrainian insurgents for food was, firstly, the result of the escalation of the confrontation over the influence areas between them, since the frequent clashes and intermittent losses of the «forest armies» only raised the degree of hostility that resulted in the unrepresentative actions of both partisan forces; secondly, in 1943 the Bolshevyk partisans were deployed in the areas with very unfavourable economic conditions; thirdly, their coercive and ill-conceived procurement campaigns exhausted the food supply potential of the local population; fourthly, during the entire period of the Nazi occupation the Soviet partisans units were constantly increasing numerically. It required the additional food and arms support for the full-fledged military activities. One should also take into account the opinion of USSR State Security organ H. Sannykov, a veteran, who believed that the reason was also rather trivial: «The local population suffered from both sides - there were the provisions requisites, organized by both hostile forces. The partisans, both Soviet and Bandera, wanted to eat -that's why the provisions were confiscated: cattle, lard, bread, potatoes and hay. All that was needed for hungry people and horses. Banderivtsi did give the peasants paper, instead of money, printed on a hectograph with a picture of a rebel with a machine gun, raised in his right hand and a sum of money $-5,10,15,25$ karbovantsiv, which, as they claimed, could be exchanged for the money of the new Ukraine after the victory. The Soviet partisans gave at best a receipt» (Sannykov, 2002, p. 300).

Before conducting the provisions operations in the territory, which was under the UPA control, the Soviet partisans were given a correspondent command, order. Thus, according to the order of RPU (Rivne Partisan Unit) № 1 of September 3, 1943, 70 partisans of F. Dzerzhynskyi, H. Kotovskyi and T. Shevchenko units were sent for conducting the operation against the nationalists in Dubrovytsia and the confiscation of their farms (CSAPAU, f. 69, d. 1, c. 5, p. 11). Before the procurement, the red (Soviet) partisans conducted intelligence to find out whether the insurgents' units could interfere with them (Vovk \& Pavlenko, 1999, 
p. 244). Meanwhile, in order not to arouse suspicion and early panic among the peasants, they could disguise themselves as Bandera insurgents. For example, in November 1943, the representative of Koretskyi district Secret Service «Winter» «Knee» noted that the Soviet partisans guerrillas, under the guise of nationalists, had robbed the village of Koseniv, Yarun district, taking away the oats from the peasants and those who did not want to give the grain were beaten (State Archives of Rivne Region-SARR, f. R-30, d. 1, c. 15, p. 27).

The Bolshevyk partisans, being aware of the presence of their hostile troops, went to take supplies in Volyn villages as the combat operations. On April 10, 1944 V. Behma, the Secretary of Rivne Regional Committee of the Communist Party (b)U stated: «For the provisions operations the partisans were forced to leave the units with numbers from 50 to 100 fighters, armed with machine guns and guns» (Kentii \& Lozytskyi, 2005, p. 375). In July 1943 the Chief of the headquarters of K. Voroshylov CHPU unit, F. Martynov reported to the headquarters that due to the resistance of the UPA, the partisans were forced to fight during the normal procurement of provisions (CSAPAU, f. 64, d. 1, c. 25, p. 93). The secretary of the underground district committee of the $\mathrm{KP}(\mathrm{b}) \mathrm{U}$ in the Volodymyretskyi district, P. Tkachuk shared the same opinion (CSAPAU, f. 166, d. 2, p. 95, p. 10). In February 1944, the commander of the 2nd Moldavian partisan unit, Ya. Shkryabach, analyzing the behaviour of V. Andreev and M. Shukaev partisan units, which functioned in the neighborhood in the south of Volyn, noted: «They carry out the procurement of provisions even by bandit methods. My The villages, in which Bandera supporters live, are under my control. So the villages are surrounded, fired upon, and then the V. Andreev and M. Shukaev partisans take whatever comes in hand. This dishonour needs to be eradicated» (Kovalchuk, 2014, p. 72).

During the successful military operations or battles against the insurgent divisions, the Soviet partisans seized the property and food from the peasants, who sympathized with the insurgents. Such a practice of the provisions requisitioning was used in the areas, where the Bandera supports opposed the Bolshevyk partisans actively. For example, on April 14, 1943, the 24th Anniversary of the Red Army detachment (RA) of the Zhytomyr Partisan Union (ZhPU) appropriated 23 heads of cattle, 16 pigs and $160 \mathrm{~kg}$ of cereals as the result of the operation to defeat the nationalist party in the village of Yelne of Rokytne district (CSAPAU, f. 65 , d. 1, c. 26, p. 233). A week later, the soldiers of V. Chapayev detachment, after the battle with the nationalists in the villages of Berezhky and Lyubykovychi of Dubrovytskyi district, appropriated the following «product trophies»: 2 oxen, 3 pigs, $20 \mathrm{~kg}$ of lard, 20 pounds of rye, 10 pounds of flour and 3 pounds of oats (CSAPAU, f. 65, d. 1, p. 26, pp. 228-229). In early June, Olevskyi detachment of Zhytomyr partisan unit appropriated 6 oxen, 2 horses and 18 poods of grain, in addition to weapons, after a similar battle in the village of Sekhy, Tomashhorod Rokytne district (CSAPAU, f. 65, d. 1, c. 17, p. 66).

Being located in Volyn region, the partisans of J. Stalin detachment, under the command of H. Balytskyi, having a low support of the local population, constantly needed replenishment of food supplies. The area, in which a hostile attitude toward the red partisans dominated, the latter carried out the economic and combat operations, as the Ukrainian insurgents had a much better food base. In this regard, H. Balytskyi wrote in his diary: «We need food. Where to get, if not from the nationalists, who have plundered a lot» (Bazhan, Vlasenko, Kentii, Legasova \& Lozitskii, 2010, p. 513). The practice of procuring products in this way, his partisans first implemented as a result of the battle with Bandera insurgents on July 17, 1943 in the village of Zhuravychi, Kivertsi district, where, in addition to the military trophies, they appropriated 200 poods of flour, 10 poods of salt, 8 poods of sugar, 150 loaves of bread, 17 pigs and 15 horses (CSAPAU, f. 64, d. 1, c. 11, p. 19; CSAPAU, f. 64, d. 1, c. 25, p. 89). 
Due to the defeat of the UPA department on July 28 in the village of Lypne July of the same district, J. . Stalin detachment appropriated 400 pounds of flour, 15 pounds of sausage, 49 pigs, 57 cattle heads and a motorcycle (CSAPAU, f. 62, d. 1, c. 1382, p. 129; Bazhan, Vlasenko, Kentii, Legasova \& Lozitskii, 2010, pp. 513-514). On August 2, M. Shchors partisan unit appropriated 14 horses, 34 heads of cattle and 15 poods of bread in the battle with the the UPA insurgents in the village of Derevok, Lyubeshiv district (CSAPAU, f. 62, d. 1, c. 1382, p. 121). On September 5, the soldiers of. J. Stalin and the NKVDB of the USSR «Hunters» conducted the economic-combat operation in the «nationalist» village of Sylne, Kivertsi district, having with task of «breaking the nationalist bastard and appropriating food» (Bazhan, Vlasenko, Kentii, Legasova \& Lozitskii, 2010, p. 556).

The UPA divisions, like the Soviet insurgents, also replenished their food supplies by using their enemy. For example, as mentioned by the insurgent F. Kondrat, in the spring of 1943, as a result of the attack of the Vorona Division on the headquarters of M. Mysyura red partisans, located in the village of Vychivka, Vysotskyi district, managed to appropriate «the warehouse with robbed peasants' goods». Those robbed the goods were transported on 17 carts to their location in Terebizhiv forest (Kondrat, 2002, pp. 20-22).

In the areas, where the insurgents constantly had to fight against the armed partisans, the above-mentioned method of providing provisions was practiced quite often.

Often, the economic operations conducting in the areas with the strong positions of the Ukrainian nationalists ended in the confrontation with them, as the latter used the tactics of attacking the small sabotage groups or the procurement partisans groups. So, on July 10, 2 platoons of partisans of S. Kirov detachment ChVPU went on the economic operation in the village of Lyubokhyn, Starovyzhiv district, where they encountered the UPA hundred. As a result of the fight, the latter lost 9 people, including the leader of the hundred. (CSAPAU, f. 64 , d. 1, c. 85 , p. 12). On December 9, V. Chapayev detachment of Ternopil partisan unit, during the economic operation in the village of Khotyn, Bereznivskyi district killed 38 insurgents and requisitioned 95 cattle heads, 47 sheep, 30 pigs and 4 horses from the peasants (CSAPAU, f. 105, d. 1, c. 20, p. 82).

In order to avoid the loss of personnel, in July $1943 \mathrm{~S}$. Kirov detachment ChVPU was forced to send the procurement groups to the remote areas, in particular, the territory bthind the Western Buh River, because their dislocation area was «clogged with nationalists in the villages, who dug in, and when approaching the village they fired from all corners, attics, etc. And where [...] they are not found, they have ordered the civilians to give nothing to the red partisans, and whoever gives something will be slaughtered and burned» (CSAPAU, f. 64, d. 1, c. 25, p. 15).

According to the documents of the Soviet partisans, for them, along with the requisition of the provisions, which belonged to the nationalists and the sympathetic population, it was a priority to destroy the households of the latter. Thus, they caused a significant damage to the Ukrainian insurgents provisions. The report on fighting in June 1943 of Sarny partisan unit stated that during the operations in the villages of Selets, Maryanivka and Strelsk of Rivne region, there were destroyed 14 nationalist households and killed 6 people (CSAPAU, f. 65, d. 1, c. 23, p. 20). At the end of August, 10 fighters of V. Molotov RPP \# 1 detachment had the task to destroy the «nationalist households» in Krushynne, Rakivka, Mokre, Dubne (CSAPAU, f. 69, d. 1, c. 41, p. 21). A security officer of the OUN «Zahrava» «Nemo» (I. Treyko (Tereyko)) noted in his report that on December 24 to the village of Rudka Podluzhanska there came the partisans detachment, which, despite the resistance of the villagers' self-defense, robbed the village, and that what «they did not have time to take with them, was destroyed» (Central State Archives of Public Associations of Ukraine-CSAPAU, f. 3833, d. 1, c. 234, p. 10). 
The requisitions of food in the villages loyal to the UPA caused a great damage to the local population and the Ukrainian insurgent underground in general. Because, as a rule, those villages were the links of the economic register of the underground, which provided food for the insurgent units, the Soviet partisans, plundering them, inflicted the considerable economic losses on the insurgent movement, thereby creating problems for its activity. It is worth agreeing with $\mathrm{H}$. Starodubets that the red partisans caused a deadly danger to the rear and were objectively regarded by the insurgent movement as the most dangerous enemies. (Starodubets, 2005, p. 292).

Conclusions. Thus, the struggle for provisions between the Soviet partisans and the Ukrainian insurgents was the result of an armed confrontation between them. At the absence of food supplies, the first ones procured it, using the Ukrainian nationalists, carrying out the preplanned operations, or obtaining the provisions as a result of the battles with the UPAunits. By requisitioning the products and property from the peasants, loyal to the Ukrainian nationalists, the Soviet partisans inflicted a considerable economic damage to the insurgent rear. In addition, such actions against the Ukrainian peasantry should be considered as an economic repression or a kind of the punitive operations.

The Bilshovyk partisans' attention to the villages, which were under control of the Ukrainian insurgent movement was also attracted by the fact that the latter were in a much better economic situation than the area of the partisans' dislocation. This was also the result of the fact that the insurgents managed to disrupt most of the requisitions of the German occupiers; they were replenishing their food mainly by means of the optimal and socially fair taxes, or by conducting voluntary givings by the locals of various kinds, as well as by organizing their own production on the territory of the underground (rear). The tangible support of the local population also helped the Ukrainian insurgent movement to have a much better provisions base than the Soviet partisans had.

Among the perspectives for further study of this topic, it is worth mentioning, firstly, the study of the process of identifying and requisitioning of the Ukrainian nationalist food bins by the Soviet partisans, and secondly, establishing the quantitative indicators of the appropriated provisions from those warehouses.

Acknowledgments. We express sincere gratitude to all members of the editorial board for consultations provided during the preparation of the article for printing.

Funding. The authors received no financial support for the research, authorship, and/or publication of this article.

\section{BIBLIOGRAPHY}

Armstrong, J. (1980). Ukrainian nationalism. Second edition. Littleton: Ukrainian Academic Press, 361 p. [in English].

Armstrong, J. (2007). Sovietskie partizany. Legenda i deystvitelnost'. 1941 - 1944 [Soviet partisans. Legend and reality. 1941 - 1944]. Moskva: Tsentrpoligraf, 493 p. [In Russian].

Bazhan, O., Vlasenko, S., Kentii, A., Legasova, L., \& Lozitskii, V. (Comps.). (2000). Partizanskaya voyna $v$ Ukraine. Dnevniki komandirov partizanskikh otriadov i soyedineniy. $1941-1944$ [Partisan war in Ukraine. The diaries of the commanders of partisan squads and formations. 1941-1944]. Moskva: Tsentrpoligraf, 670 p. [in Russian].

Centralnyi Derzhavnyi Arhiv Hromadskykh Obyednan Ukrainy [Central State Archives of Public Associations of Ukraine - CSAPAU].

Centralnyi Derzhavnyi Arkhiv Vyshchykh Orhaniv Vlady i Upravlinnia Ukrainy [Central State Archives of the Supreme Bodies of Power and Management of Ukraine-CSASBPMU].

Derzhavnyi Arkhiv Rivnenskoi Oblasti [State Archives of Rivne Region-SARR]. 
Gogun, A. (2012). Stalinskiye kommandos. Ukrainskiye partizanskiye formirovaniya 1941 1944 [The Stalin's Commandos. Ukrainian partisan formations 1941 - 1944] (2-nd ed.). Moskva: ROSSPEN, 527 p. [in Russian].

Kentii, A., \& Lozytskyi, V. (2010). Radianski partyzany 1941 - 1944: svitlo i tini [Soviet partisans 1941 - 1944: light and shadow]. Kyiv, 80 p. [in Ukrainian].

Kentii, A. (2008). Zbroinyi chyn ukrayiskykh natsionalistiv. 1920 - 1956. Istoryko-arkhivni narysy. Ukrayinska povstanska armiya ta zbroyne pidpillia Organizatsii ukrayinskykh natsionalistiv. 1942 - 1956 [The armed action of Ukrainian nationalists. 1920-1956. Historical and archival essays. Ukrainian Insurgent Army and Armed Underground Organization of Ukrainian Nationalists. 1942 1956]. (Vol. 2.). Kyiv: Derzhavnyj komitet arkhiviv Ukrayiny, 416 p. [in Ukrainian].

Kentii, A., \& Lozytskyi, V. (2005). Viyna bez poschady i myloserdya. Partyzans'kyy front u tylu Vermakhtu v Ukrayini 1941 - 1944 [The War without mercy and clemency. Partisan Front at the rear of the Wehrmacht in Ukraine 1941 - 1944]. Kyiv: Geneza, 408 p. [in Ukrainian].

Kentii, A., Lozytskyi, V., \& Slobodianiuk, M. (2010). Radianskyi rukh Oporu na okupovanii terytorii Ukrainy [The Soviet resistance movement in the occupied territory of Ukraine]. Kyiv: Instytut Istoriyi NANU, 98 p. [in Ukrainian].

Kondrat, F. (2002). My staly voli na storozhi [We started to vigil for the freedom]. Ivano-Frankivsk: Lileya-NV, 112 p. [in Ukrainian].

Kovalchuk, V. (Comp.). (2007). Litopys UPA. Nova seriya [Chronicle of the UPA. New series]. (Vol. 11): Merezha OUN (b) i zapillya UPA na terytoriyi VO «Zahrava», «Turiv», "Bohun» (serpen" 1942 - gruden' $1943 \mathrm{rr}$.). [The network of UPA and underground on the territory of the military units "Zahrava», «Turiv», "Bohun» in August of 1942 - December of 1943]. Kyiv; Toronto: Litopys UPA, 845 p. [in Ukrainian].

Kyzia, L. (1960). Narodni mesnyky: z istoriyi partyzanskoho rukhu na Rovenshchyni [People's avengers: from the history of the partisan movement in the Rovno region]. Lviv: Knyzhkovo-zhurnalne vydavnytstvo, $172 \mathrm{p}$. [in Ukrainian].

Perekhrest, O. (2011). Ukrayinske selo v 1941 - 1945 rr.: ekonomichne ta sotsialne stanovyshche [Ukrainian village in 1941 - 1945: economic and social situation]. Cherkasy: ChNU, 668 p. [in Ukrainian].

Sannykov, G. (2002). Bolshaya okhota. Razgrom vooruzhennogo podpol'ya v Zapadnoy Ukraine [Great hunting. The defeat of the armed underground in the Western Ukraine]. Moskva: OLMAPRESS, 512 p. [in Russian].

Starodubets, G. (2005). Ukrayinske povstanske zapillya yak obyekt interesiv vijskovo-politychnykh chynnykiv kincya 1943 - 1944 rr. [Ukrainian insurgent underground as an object of interests of military-political factors of the end of 1943 - 1944]. Naukovi praci istorychnogo fakultetu Zaporizkogo derzhavnogo universytetu - Scientific works of the historical faculty of The Zaporizhzhia State University, (19), 288-293. [in Ukrainian].

Starodubets, G. (2008). Geneza ukrayins'kogo povstans'kogo zapillya [Genesis of the Ukrainian Insurgent Underground]. Ternopil: Pidruchnyky i posibnyky, 464 p. [in Ukrainian].

Stepanov, L. (1966). Do istoriyi antyfashystskoyi borotby na Rivnenshchyni (1941 - 1944) [To the history of anti-fascist struggle in the Rivne region (1941 - 1944)]. Lviv: Kameniar, 109 p. [in Ukrainian].

Sukhykh, A. (2014). Povstansko-pidpilnyi rukh na Novograd-Volynschyni (1941 - 1943) [Rebellion-underground movement on the Novograd-Volynskyi region (1941 - 1943)]. Ukrayina: kulturna spadschyna, nacionalna svidomist, derzhavnist - Ukraine: cultural heritage, national consciousness, statehood, 24, 362-374. [in Ukrainian].

Vovk, O., \& Pavlenko, I. (Comps.). (1999). Litopys UPA. Nova seriya. [Chronicle of the UPA. New series]. (Vol. 2): Volyn'ta Polissya: UPA ta zapillya 1943 - 1944: Dokumenty ta materialy [The Volhynia and Polesia: UPA and underground 1943 - 1944: Documents and materials]. Kyiv; Toronto: Litopys UPA, 724 p. [in Ukrainian].

Zamlynskyi, V. (1965). Karayucha zemlia: pro komunistyczne pidpillia i partyzans'kyi rukh na Volyni v roky Velykoi Vitchyznianoyi viyny [Chastise Land: About the Communist Underground and the Partisan Movement in Volhynia during the Great Patriotic War]. Lviv: Kameniar, 259 p. [in Ukrainian].

The article was received on March 25, 2019. Article recommended for publishing 27/08/2019. 